\title{
PENGARUH RELATIONSHIP MARKETING, CITRA PERUSAHAAN DAN KEPUASAN TERHADAP LOYALITAS NASABAH (STUDI PADA BANK RAKYAT INDONESIA SYARIAH KANTOR CABANG SEMARANG)
}

\author{
Nurudin \\ FEBI UIN Walisongo Semarang
}

\begin{abstract}
This study aims to find out how the influence of relationship marketing, corporate image and satisfaction of customer loyalty Bank Rakyat Indonesia Sharia Branch Office of Semarang. The data used in this study is the primary data obtained through this questionnaire is distributed to customers of customers of Bank Rakyat Indonesia Syariah Branch Semarang. The analysis method used is multiple linear regression analysis.

The results of this study indicate that the relationship marketing (X1) variable has a significant influence on customer loyalty, it is shown p value (sig) of 0.000 below 0.05. Corporate image variable (X2) has significant influence to customer loyalty, it is shown p value (sig) equal to 0,023 below 0,05. Likewise with the satisfaction variable (X3) has a significant influence on customer loyalty, this is indicated by $p$ value (sig) of 0.009 below 0.05 .
\end{abstract}

Keywords: relationship marketing, corporate image, satisfaction, customer loyalty.

\begin{abstract}
ABSTRAK
Penelitian ini bertujuan untuk mengetahui bagaimana pengaruh relationship marketing, citra perusahaan dan kepuasan terhadap loyalitas nasabah Bank Rakyat Indonesia Syariah Kantor Cabang Semarang. Data yang digunakan dalam penelitian ini adalah data primer yang diperoleh melalui kuesioner ini dibagikan kepada nasabah nasabah Bank Rakyat Indonesia Syariah Cabang Semarang. Metode analisis yang digunakan adalah analisis regresi linear berganda.

Hasil penelitian ini menunjukan bahwa variabel relationship marketing (X1) memiliki pengaruh signifikan terhadap loyalitas nasabah, hal ini ditunjukkan pvalue (sig) sebesar 0,000 di bawah 0,05. Variabel citra perusahaan (X2) memiliki pengaruh signifikan terhadap loyalitas nasabah, hal ini ditunjukkan pvalue (sig) sebesar 0,023 di bawah 0,05. Begitu juga dengan variabel kepuasan (X3) memiliki pengaruh signifikan terhadap loyalitas nasabah, hal ini ditunjukkan dengan pvalue (sig) sebesar 0,009 di bawah 0,05 .
\end{abstract}

Kata kunci: relationship marketing, citra perusahaan, kepuasan, loyalitas nasabah. 


\section{Pendahuluan}

Latar Belakang Masalah

Dalam menghadapi persaingan yang semakin ketat, Bank harus mampu menunjukkan berbagai kelebihan serta keunggulan tertentu dari para pesaingnya. Pesaing bank bukan hanya sesame bank, baik bank nasional maupun bank asing, tetapi juga dengan lembaga keuangan bukan bank, seperti modal ventura, leasing dan lembaga pembiayaan lainnya. Dalam kondisi yang demikian bank tidak boleh hanya duduk menunggu datangnya nasabah, bank dituntut untuk bersikap lebih agresif dan bekerja lebih profesional.

Berbagai upaya dilakukan bank untuk tetap bertahan hidup (survive), disamping harus mengahadapi persaingan yang sangat ketat, bank perlu mempertahankan pelanggan agar tetap loyal terhadap perusahaan. Tjiptono (2000) mengemukakan bahwa loyalitas nasbah adalah komitmen pelanggan terhadap suatu merk, toko, atau pemasok berdasarkan sifat yang positif dalam pembelian jangka panjang. Loyalitas pelanggan sangat penting bagi perusahaan agar dapat berkembang dan meneruskan usahanya. Salah satu faktor yang dapat membentuk loyalitas pelanggan adalah kepuasan pelanggan. Menurut Aryani dan Rosinta (2010), pelanggan yang menikmati layanan kemungkinan besar akan berkata positif tentang perusahaan dan jarang melakukan perpindahan merek. Menurut Kotler (2007), kepuasan pelanggan adalah perasaan senang atau kecewa seseorang yang muncul setelah membandingkan antara persepsi atau kesannya terhadap kinerja atau hasil suatu produk dan harapan-harapannya. Dengan kata lain, pelanggan akan merasa puas jika harapannya terpenuhi. Dengan mengetahui tingkat kepuasan pelanggan, perusahaan dapat melakukan antisipasi terhadap kriteria dari suatu produk.

Keberhasilan pemasaran suatu produk sering tidak cukup hanya dengan menawarkan berbagai keunggulan yang dimiliki oleh jasa tersebut. Keberhasilan pemasaran tersebut hanya bisa dicapai melalui penerapan strategi pemasaran yang melibatkan perusahaan dan nasabah. Lebih tepatnya, agar berhasil dalam pemasaran, perusahaan harus melaksanakan suatu hubungan pemasaran pelanggan customer 
relationship marketing yang baik. Pada dasarnya customer relationship marketing bertujuan untuk proses adaptasi antara perusahaan dengan pelanggannya. customer relationship marketing mampu memberdayakan kekuatan keinginan pelanggan dengan tekanan teknologi informasi untuk memberikan kepuasan pada nasabah sehingga memperpanjang hubungan dengan nasabah. customer relationship marketing berusaha membangun hubungan dan perhatian yang lebih kontruktif dengan pelanggan terpilih dan terseleksi lebih penting dalam memperluas sukses pemasaran jangka panjang dibandingkan hanya mengejar target pengumpulan perhatian publik dalam skala yang lebih luas. Keberhasilan pemasaran suatu produk sering tidak cukup hanya dengan menawarkan berbagai keunggulan yang dimiliki oleh jasa tersebut. Justru yang terpenting adalah apakah penyediaan produk tersebut sudah sesuai dengan keinginan dan dapat memenuhi kebutuhan nasabah sehingga dapat meningkatkan nilai nasabah (customer value). Keberhasilan pemasaran tersebut hanya bisa dicapai melalui penerapan strategi pemasaran yang melibatkan perusahaan dan nasabah.

Meskipun banyak pihak setuju bahwa keberhasilan sebuah bank ditentukan oleh kemampuan bank tersebut dalam membangun loyalitas nasabah, loyalitas tersebut akan menjadi salah satu tujuan yang harus dicapai oleh suatu bank dalam hal mempertahankan nasabahnya. Berbagai konsep yang berkembang saat ini menyiratkan bahwa citra sebuah perusahaan sangat penting sebagai sarana atau alat untuk meraih keunggulan bersaing di pasar. Untuk dapat maju dan terus berkembang, perusahaan harus membuktikan bahwa perusahaan tersebut dapat dipercaya. Memiliki image yang baik dimata masyarakat akan menjadi konsekuensi dari pembentukan citra. Citra dapat mendukung dan merusak nilai yang konsumen rasakan. Citra yang baik akan mampu meningkatkan kesuksesan suatu perusahaan dan sebaliknya citra yang buruk akan memperpuruk kestabilan suatu perusahaan. Istijanto, (2005) mengemukakan bahwa perusahaan yang memiliki citra atau reputasi yang baik akan mendorong konsumen membeli produk yang ditawarkan, mempertinggi kemampuan bersaing, mendorong semangat kerja karyawan, dan meningkatkan loyalitas pelanggan. 
BRI Syariah telah menjadi bank syariah yang ketiga terbesar berdasarkan jumlah asetnya. BRI Syariah tumbuh sangat pesat baik dari sisi aset, jumlah pembiayaan maupun perolehan dana pihak ketiga. Dengan berfokus di segmen menengah bawah, Bank BRI Syariah menargetkan menjadi bank ritel modern terkemuka dengan berbagai ragam produk dan layanan perbankan. Sebagai Kantor Layanan Syariah dalam mengembangkan bisnis yang berfokus pada penghimpunan dana dari masyarakat dan kegiatan lainnya berdasarkan prinsip-prinsip syariah. Berdasarkan data jumlah dana simpanan wadiah dari nasabah BRI Syariah (dalam jutaan rupiah)Pada bulan januari 2017 sebesar Rp 5.217.449, bulan Feberuari 2017 sebesarRp. 5.350.413, bulan Maret 2017 sebesar Rp. 5.494.279, bulan April 2017 sebesar Rp. 6.192.659, bulan Mei 2017 sebesar Rp. 6.475.070, bulan Juni 2017 Rp. 5.728.226 dan pada bulan Juli 2017 sebesar Rp. 5.726.399.dari data tersebut terjadi peningkatanjumlah dana simpanan wadiahpada bulan Januari 2017 - Mei 2017, sedangkan pada bulan Juni 2017 dan Juli 2017 mengalami penurunan jumlah dana simpanan wadiah.

\section{Masalah Penelitian}

Dari uraian di atas maka dapat dapat dirumuskan masalah penelitian sebagai berikut:

1. Bagaimana pengaruh Relationship Marketing terhadap loyalitas nasabah Bank Rakyat Indonesia Syariah Kantor Cabang Semarang?

2. Bagaimana pengaruh Citra Perusahaan terhadap loyalitas nasabah Bank Rakyat Indonesia Syariah Kantor Cabang Semarang?

3. Bagaimana pengaruh Kepuasan terhadap loyalitas nasabah Bank Rakyat Indonesia Syariah Kantor Cabang Semarang?

\section{Kajian Teoritis}

1. Pemasaran

Pemasaran adalah suatu fungsi organisasi dan seperangkat konsep untuk menciptakan, mengomunikasikan, dan menyerahkan nilai kepada pelanggan dan mengelola hubungan pelanggan dengan cara yang menguntungkan organisasi dan para pemilik sahamnya. 
Atau disini dijelaskan bahwa pemasaran adalah suatu proses sosial yang didalamnya individu dan kelompok mendapatkan apa saja yang mereka butuhkan dan inginkan dengan menciptakan, menawarkan dan secara bebas mempertukarkan produk yang bernilai dengan pihak lain (Philip Kotler, 2016: 6-7).

Pemasaran sebagai kegiatan manusia yang diarahkan untuk memenuhi dan memuaskan kebutuhan dan keinginan melalui proses pertukaran (Sofyan, 2011:5). Pengertian lainnya menurut Abdullah dan Tantri, pemasaran adalah proses sosial dan manajerial dimana individu dan kelompok mendapatkan kebutuhan dan keinginan mereka dengan menciptakan, menawarkan dan menukarkan produk yang bernilai satu sama lain (Abdullah dan Tantri, 2013: 22). Dari beberapa pengertian diatas dapat disimpulkan bahwa pemasaran merupakan suatu proses kegiatan yang di dalamnya terdiri dari individu maupun organisasi untuk menciptakan, menawarkan dan mengelola hubungan pelanggan untuk mempertukarkan produk dalam rangka memenuhi kebutuhan.

\section{Relationship Marketing}

Relationship Marketing dapat mengarahkan pada adanya peningkatan produktivitas pemasaran jika implementasi relationshipmarketing dilakukan secara efektif dan efisien. Relationship marketing berupaya menjalin hubungan jangka panjang dengan para pelanggan, dimana terdapat hubungan yang kokoh dan saling menguntungkan antara penyedia jasa dan pelanggan yang dapat membangun transaksi ulangan dan menciptakan loyalitas pelanggan (Murry, 2010:72).

Relationship marketing sangat penting dalam pemasaran karena dapat menimbulkan hubungan baik antara produsen dan konsumen sehingga dapat menambah nilai masa depan. Relationship marketing merupakan salah satu strategi untuk menyelaraskan kompetensi, teknologi dan sumber daya yang dimiliki dengan kebutuhan dan keinginan pelanggan yang dinamis untuk pemasaran. Pada saat ini relationship marketig merupakan hal yang dibutuhkan bagi para pelakunya karena perkembangan 
kompetisi global mengakibatkan konsumen lebih pintar dan teliti untuk memilih dan memutuskan apa yang diinginkannya.

Relationship marketing sebagai upaya mengembangkan relasi berkesinambungan dengan para pelanggan kaitannya dengan serangkaian produk dan jasa terkait. Relationship marketing juga sebagai upaya mengembangkan, mempertahankan, meningkatkan dan mengkomersialisasikan relasi pelanggan dalam rangka mewujudkan tujuan semua pihak yang terlibat.

Relationship marketing sebagai segala aktivitas pemasaran yang diarahkan pada membangun, mengembangkan dan mempertahankan pertukaran relational yang sukses (fandy, 2012:413). Relationship marketing adalah proses menciptakan, mempertahankan dan memperbaiki hubungan yang kuat berdasarkan nilai, dengan pelanggan dan pemegang saham lainnya. Sedangkan Chan dalam Murry, mendefinisikan relationship marketing sebagai pengenalan setiap pelanggan secara lebih dekat dengan menciptakan komunikasi dua arah dengan mengelola suatu hubungan yang saling menguntungkan antara pelanggan dan perusahaan.

Relationship marketing adalah proses berkelanjutan yang mensyaratkan suatu perusahaan agar menjalin komunikasi tetap dengan konsumen untuk memastikan tujuan tercapai, dan memadukan proses relationship marketing kedalam rencana strategik sehingga memungkinkan perusahaan mengelola sumber daya dengan baik dan memenuhi kebutuhan konsumen di masamendatang. Dapat disimpulkan bahwa relationship marketing adalah upaya aktivitas pemasaran dalam rangka menciptakan, membangun, mengembangkan, mempertahankan, memperbaiki, meningkatkan relasi jangka panjang kepada semua pihak yang terlibat, secara lebih dekat dan terjalinnya suatu komunikasi antara perusahaan dengan pelangan secara berkesinambungan dan saling menguntungkan.

Relationship marketing menerapkan suatu hubungan yang baik kepada pelanggan. Hubungan yang baik dengan siapapun akan mendatangkan keharmonisan, kemudahan dalam mencari rezeki, bisa mengatasi seberat apapun persoalan yang 
dihadapi, dan pada akhirnya akan mendatangkan kebahagiaan, jika sebaliknya, maka akan menimbulkan berbagai masalah yang berkepanjangan (Ali Hasan, 2002:74).

\section{Citra Perusahaan}

Pengertian citra adalah apa yang dipikirkan konsumen tentang suatu produk. Termasuk didalamnya adalah persepsi dan sikap yang didasarkan pada reaksi dan rangsangan yang berkaitan dengan perusahaan yang diterima melalui kelima indera (Peter dan Olson, 2000:248-24). Kotler (1997:57), “citra (image) adalah kepercayaan, ide dan impresi seseorang terhadap sesuatu".

Bagi sebuah perusahaan, image atau citra yang baik mutlak diperlukan. Sedemikian penting arti dari citra (image) itu sendiri sehingga perusahaan bersedia mengeluarkan biaya dan tenaga ekstra untuk meraihnya. Citra (image) merupakan seperangkat keyakinan, ide, dan pesan yang dimiliki seseorang terhadap suatu objek (Kotler, 1995, dalam Sutisna, 2001:33).

Citra adalah tujuan utama dan sekaligus merupakan reputasi dan prestasi yang hendak dicapai public relations. Meskipun demikian pengertian citra itu sendiri abstrak (intangible) dan tidak dapat diukur. Kotler (2000) dalam Nova, (2011: 298) menjelaskan pengertian citra adalah persepsi masyarakat terhadap perusahaan atau produknya.

Citra dipengaruhi oleh banyak faktor di luar kontrol perusahaan. Menurut Jasfar (2005), citra suatu perusahaan yang meliputi nama baik perusahaan, reputasi ataupun keahliannya merupakan faktor yang sering mempengaruhi keputusan pembeli dan sektor jasa dibandingkan sektor produk.

\section{Kepuasan Nasabah}

Kepuasan nasabah merupakan hal yang penting bagi penyelenggara jasa, karena nasabah akan menyebarluaskan rasa puasnya kepada calon nasabah, sehingga akan menaikkan reputasi pemberi jasa. Menurut Zeithaml dan Bitner (2000) definisi kepuasan adalah respon atau tanggapan konsumen mengenai pemenuhan kebutuhan. 
Kepuasan merupakan penilaian mengenai ciri atau keistimewaan produk atau jasa, atau produk itu sendiri, yang menyediakan tingkat kesenangan konsumen berkaitan dengan pemenuhan kebutuhan konsumsi konsumen.

Kemudian menurut Kasmir, (2004:67-68) komponen kepuasan dalam dunia perbankan adalah :

1) Tangible, merupakan bukti fisik yang harus dimiliki oleh karyawan bank, seperti gedung, perlengkapan kantor, daya tarik karyawan, sarana komunikasidan sarana fisik lainnya. Oleh karena itu, bukti fisik ini harus menarik dan modern.

2) Responsivitas, yaitu adanya keinginan dan kemauan karyawan bank dalam memberikan pelayanan kepada pelanggan.Untuk itu pihak manajemen bank perlu memberikan motivasi yang besar agar seluruh karyawan bank mendukung kegiatan pelayanan kepada nasabah tanpa pandang bulu.Akanmendukung kegiatan pelayanan kepada nasabah tanpa pandang bulu.Akan lebih baik jika motivasi yang diberikan kepada karyawan akan memperoleh imbalan yang sesuai dengan kemampuannya.

3) Assurance, adanya jaminan bahwa karyawan memiliki pengetahuan, kompetensi, kesopanan dan sifat atau perilaku yang dapat dipercaya. Hal ini penting agar nasabah yakin akan transaksi yang mereka lakukan benar dan tepat sasaran.

4) Reliabilitas, yaitu kemampuan bank dalam memberikan pelayanan yang telah dijanjikan dengan cepat, akurat serta memuaskan pelanggannya. Guna mendukung hal ini maka setiap karyawan bank sebaliknya diberikan pelatihan dan pendidikan guna meningkatkan kemampuannya.

5) Empati, yaitu mampu memberikan kemudahan serta menjalin hubungan dengan nasabah secara efektif. Kemudian juga mampu memahami kebutuhan individu setiap nasabah secara cepat dan tepat.Dalam hal ini masalah prosedur kerja dan dihubungkan dengan tingkat pelayanan kepada nasabah. 


\section{Loyalitas}

Secara harfiah loyalitas dapat diartikan sebagai suatu kesetiaan. Kesetiaan ini timbul tanpa adanya paksaan, tetapi timbul dari kesadaran sendiri pada masa lalu atau merupakan sikap pendukung yang menguatkan kepercayaan banyak orang. Loyalitas berhubungan dengan kesetiaan dan komitmen jangka panjang (M. Ma'ruf Abdullah :2011:54.). Kesetian adalah komitmen yang kuat untuk kembali membeli atau pengulangan pembelian pada produk dan jasa yang di suka secara konsisten dimasa datang.Kesetiaan dan kesediaan konsumen untuk membeli suatu produk secara terus menerus pada pengecer yang sama dapat terjadi apabila konsumen merasa puas dengan kinerja perusahaan (Nurudin, 2017: 49).

Menurut kotler dan keller dalam Raymond Setia Budi dan Sabrina Oktoria Sihombing mendefinisikan loyalitas sebagai komitmen mendalam untuk kembali membeli sebuah barang atau jasa di masa yang akan datang tanpa memperdulikan situasi yang terjadi dan adanya akibat dari perpindahan (Raymond Setia Budi dan Sabrina Oktoria Sihombing, 2010:68-69).

Loyalitas pelanggan merupakan kesetiaan pelanggan terhadap penyedia jasa yang telah memberikan pelayanan kepadanya. Loyalitasdapat diukur dengan tiga indikator, yaitu:

1) Repeat, yaitu apabila pelanggan membutuhkan barang atau jasa yang disediakan oleh penyedia jasa yang bersangkutan

2) Retention, yakni ia tidak terpengaruh jasa yang ditawarkan oleh pihak lain.

3) Referral, apabila jasa yang diterima memuaskan, maka pelanggan akan memberitahukan kepada pihak lain, dan sebaliknya apabila ada ketidakpuasan atas pelayan yang diterima ia tidak akan bicara pada pihak lain, tapi justru akan memberitahukan layanan yang kurang memuaskan tersebut pada pihak penyedia dana. 
Menurut Tjiptono terdapat empat sikap dan perilaku pembelian ulang yaitu no loyalty, spurious loyalty, latent loyalty, loyalty, antara lain:

1) No Loyalty Bila sikap dan perilaku pembelian ulang pelanggan sama-sama lemah, maka loyalitas tidak terbentuk. Ada dua kemungkinan penyebab, yang pertama sikap yang lemah (mendekati netral) dapat terjadi bila suatu produk atau jasa baru diperkenalkan dan atau pemasarannya tidak mampu mengkonsumsikan keunggulan unik produknya. Penyebab yang kedua berkaitan dengan dinamika pasar, dimana merek-merek yang berkompetisi dipersepsikan serupa atau sama. Konsekuensinya, pemasar mungkin sangat sukar membentuk sikap yang positif atau kuat terhadap produk atau perusahaannya.

2) Suporious Loyalty Spurious loyalty, bila sikap yang relatif lemah disertai pola pembelian ulang yang kuat, maka yang terjadi adalah spurious loyalty atau captive loyalty. Situasi semacam ini ditandai dengan pengaruh faktor non-sikap terhadap perilaku, misalnya norma subyektif dan faktor situasional. Situasi ini dapat dikatakan pula inertia, dimana konsumen sulit membedakan berbagai merek dalam kategori produk dengan keterlibatan rendah, sehingga pembelian ulang dilakukan atas dasar pertimbangan situasional.

3) Latent Loyalty situasi latent loyalty tercermin bila sikap yang kuat disertai pola pembelian ulang yang lemah. Situasi yang menjadi perhatian besar para pemasar ini disebabkan pengaruh faktorfaktor non-sikap yang sama kuat atau bahkan cenderung lebih kuat dari pada faktor sikap dalam menentukan pembelian ulang.

4) Loyalty Situasi ini merupakan situasi ideal yang paling diharapkan para pemasar, di mana konsumen bersikap positif terhadap jasa atau penyedia jasa bersangkutan dan disertai pola pembelian ulang yang konsisten (Fandy, 2012:399). 
Kerangka Pemikiran

Gambar 1.Kerangka Pemikiran Teoritis

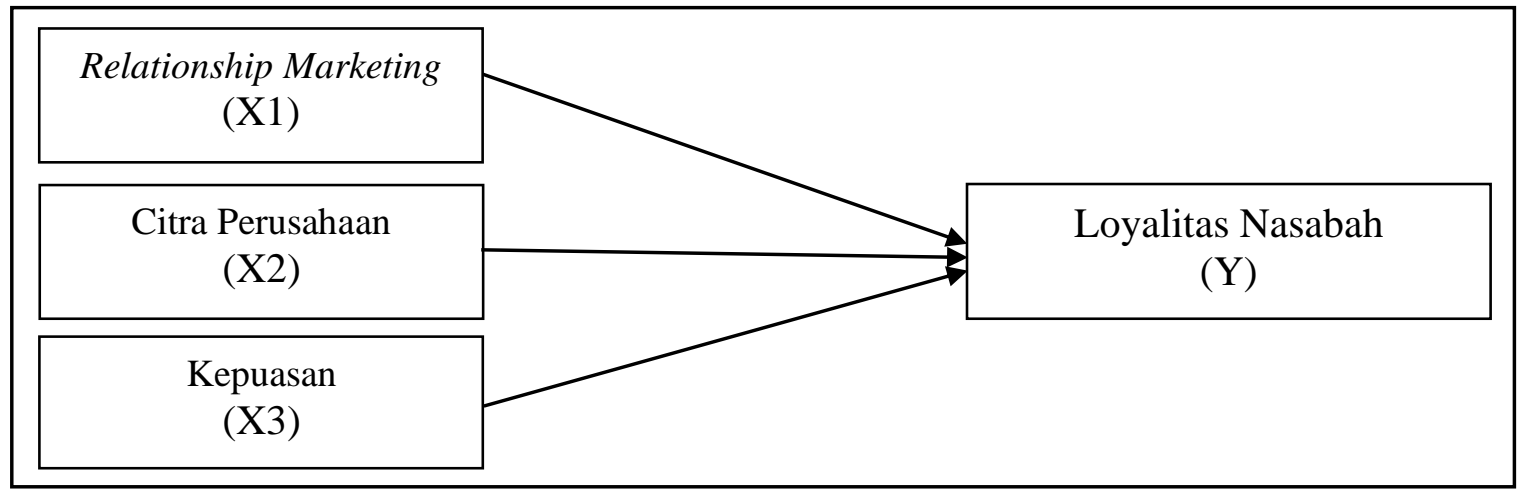

Sumber : konsep yang dikembangkan dalam penelitian ini, 2017.

\section{Metodologi}

\section{Jenis dan Sumber Data}

Data adalah bahan keterangan tentang sesuatu objek penelitian yang diperoleh dilokasi penelitian. Adapun jenis penelitian ini dikategorikan sebagai penelitian lapangan, karena data yang diperoleh dari hasil pengamatan langsung pada nasabah Bank BRI Syariah KC Semarang (Burhan Bungin, 2006: 119).

Adapun sumber data yang digunakan dalam penelitian ini adalah sebagai berikut:

1) Data primer adalah data yang dikumpulkan dan diolah sendiri oleh suatu organisasi atau perorangan langsung dari objeknya. Data ini diperoleh langsung dari penyebaran angket yang diberikan kepada nasabah Bank BRI Syariah KC Semarang sebagai responden yang terpilih untuk dijadikan penelitian.

2) Data sekunder adalah data yang diperoleh dalam bentuk yang sudah jadi, sudah dikumpulkan dan diolah oleh pihak lain (Singgih Santoso dan Fandy Tjiptono, 2001:59). Data sekunder dalam penelitian ini diperoleh dari literature-literatur, jurnal penelitian dan data tentang Bank BRI Syariah KC Semarang, yaitu mengenai gambaran umum tentang perusahaan. 


\section{Populasi dan Sampel}

Menurut Sugiyono (2004) populasi adalah wilayah generalisasi yang terdiri dari atas objek atau objek yang mempunyai karakteristik tertentu yang ditetapkan oleh peneliti dan kemudian ditarik kesimpulannya. Populasi sasaran dalam penelitian ini adalah nasabah Bank BRI Syariah KC Semarang.

Menurut Sugiyono (2012) sampel adalah sebagian dari jumlah dan karakteristik yang dimiliki oleh populasi tersebut. Untuk menentukan jumlah sampel dilakukan sebuah sampling. Teknik sampling yang digunakan dalam penelitian ini ialah sampling insidental. Dalam penelitian ini kriteria utamanya ialah orang tersebut merupakan nasabah Bank BRI Syariah KC Semarangdengan jumlah 100 responden.

\section{Metode Pengumpulan data}

Metode pengumpulan data merupakan langkah yang dapat menentukan berhasil tidaknya suatu penelitian. Oleh karena itu pemilihan metode pengumpulan data yang tepat akan memperoleh data yang relevan dan akurat. Metode pengumpulan data dalam penelitian ini yaitu :

\section{1) Kuesioner}

Kuesioner merupakan suatu alat pengumpul informasi dengan cara menyampaikan sejumlah pertanyaan tertulis untuk dijawab secara tertulis pula oleh responden.Kuesioner merupakan teknik pengumpulan data yang efisien bila peneliti tahu dengan pasti variabel yang akan diukur dan tahu apa yang bisa diharapkan dari responden (Nurul Zuriah, 2006:182.). Dalam penelitian ini kuisioner dibagikan kepada nasabah yang termasuk didalam sampel yang berjumlah 100 nasabah. Disini nasabah diberikan daftar pertanyaan-pertanyaan dan berkewajiban untuk menjawab sesuai dengan alur yang telah ditentukan peneliti.

Instrumen yang digunakan untuk mengukur variabel penelitian ini dengan menggunakan skala likert. Skala likert digunakan untuk mengukur tanggapan atau respons seseorang tentang obyek sosial. Dalam penelitian, obyek sosial telah ditetapkan secara spesifik oleh peneliti yang selanjutnya disebut sebagai variabel 
penelitian. Dengan skala likert, maka variable penelitian yang akan di ukur dijabarkan menjadi indikator variabel. Kemudian indikator tersebut dijadikan sebagai titik tolak untuk menyusun item-item instrumen yang dapat berupa pertanyaan atau pernyataan.

Jawaban setiap instrumen yang menggunakan skala likert mempunyai gradasi dari sangat positif sampai sangat negatif. Apabila item bernilai sangat positif maka angka terbesar diletakkan pada "sangat setuju“,sedangkan jika item bernilai negatif maka angka terbesar diletakkan pada " sangat tidak setuju ". Berikut adalah daftar penilaian dalam skala likertyaitu:
1. Sangat setuju
skor 5
2. Setuju
skor 4
3. Ragu-ragu
skor 3
4. Tidak setuju
skor 2
5. Sangat tidak setuju
skor 1.

2) Dokumentasi

Dokumentasi digunakan untuk pengumpulan data berupa data tertulis yang mengandung keterangan dan penjelasan serta pemikiran tentang fenomena yang masih aktual dan sesuai dengan masalah penelitian. Misalnya berupa arsip-arsip, buku-buku catatan yang lainnya yang berhubungan dengan penelitian ini (Muhammad, 2008:152.). Dokumentasi yang digunakan yaitu yang berhubungan dengan profil tentang Bank BRI Syariah KC Semarang.

4. Metode Analisis Data

Metode yang digunakan untuk menganalisis hubungan antara variabel independen dengan variabel dependen adalah metode regresi linier berganda sebagai berikut :

$$
\mathrm{Y}=\mathrm{a}+\mathrm{bX} 1+\mathrm{bX} 2+\mathrm{bX} 3+\mathrm{e}
$$

Dimana:

$$
\begin{aligned}
\mathrm{Y} & =\text { Loyalitas Nasabah } \\
\mathrm{a} & =\text { Nilai konstanta }
\end{aligned}
$$




$$
\begin{aligned}
& \mathrm{b}=\text { Koefisien regresi } \\
& \mathrm{X} 1=\text { Relationship Marketing } \\
& \mathrm{X} 2=\text { Citra Perusahaan } \\
& \mathrm{X} 3=\text { Kepuasan }
\end{aligned}
$$

\section{Pembahasan}

1. Uji Validitas dan Reliabilitas instrumen

Tabel 1

Hasil Uji Validitas Instrumen

\begin{tabular}{cccccc}
\hline No & Variabel & Indikator & $\mathrm{r}_{\text {hitung }}$ & $\mathrm{r}_{\text {tabel }}$ & Keterangan \\
\hline \multirow{4}{*}{1} & Loyalitas & P1 & 0,972 & 0,361 & Valid \\
& Nasabah & P2 & 0,764 & 0,361 & Valid \\
& & P3 & 0,900 & 0,361 & Valid \\
& & P4 & 0,865 & 0,361 & Valid \\
\multirow{4}{*}{2} & P1 & 0,891 & 0,361 & Valid \\
& Relationship & P2 & 0,976 & 0,361 & Valid \\
& Marketing & P3 & 0,824 & 0,361 & Valid \\
& & P4 & 0,928 & 0,361 & Valid \\
& & P5 & 0,414 & 0,361 & Valid \\
& & P1 & 1,251 & 0,361 & Valid \\
& Citra & P2 & 0,999 & 0,361 & Valid \\
& Perusahaan & P3 & 0,840 & 0,361 & Valid \\
& & P4 & 0,929 & 0,361 & Valid \\
& & P5 & 0,932 & 0,361 & Valid \\
& & P1 & 0,581 & 0,361 & Valid \\
4 & Kepuasan & P2 & 0,847 & 0,361 & Valid \\
& & P3 & 0,692 & 0,361 & Valid \\
& & P4 & 1,148 & 0,361 & Valid \\
& & P5 & 0,736 & 0,361 & Valid \\
\hline
\end{tabular}

Sumber : Data Primer yang diolah, 2017

Dari tabel di atas dapat diketahui bahwa masing-masing item pernyataan memiliki $r$ hitung $>$ dari $r$ tabel $(0,361)$ dan bernilai positif. Dengan demikian butirbutir pernyataan tersebut dinyatakan valid. 
Tabel 2

Hasil Uji Reliabilitas Instrument

\begin{tabular}{clccc}
\hline No & \multicolumn{1}{c}{ Variabel } & $\mathrm{r}_{11}$ & $\mathrm{r}_{\text {tabel }}$ & Ket \\
\hline 1 & Loyalitas Nasabah & 0,890 & 0,361 & Reliabel \\
2 & Relationship Marketing & 0,877 & 0,361 & Reliabel \\
3 & Citra Perusahaan & 0,991 & 0,361 & Reliabel \\
4 & Kepuasan & 0,879 & 0,361 & Reliabel \\
\hline
\end{tabular}

Sumber : data Primer yang diolah, 2017

Dari keterangan tabel di atas dapat diketahui bahwa masing-masing variabel penelitian memiliki r11 lebih dari 0,361 sehingga dapat disimpulkan bahwa semua variabel penelitian adalah reliabel.

2. Uji Asumsi Klasik

Uji Normalitas

Gambar 2. Grafik Normal P-P Plot

Normal P-P Plot of Regression Standardized Residual

Dependent Variable: Loyalitas

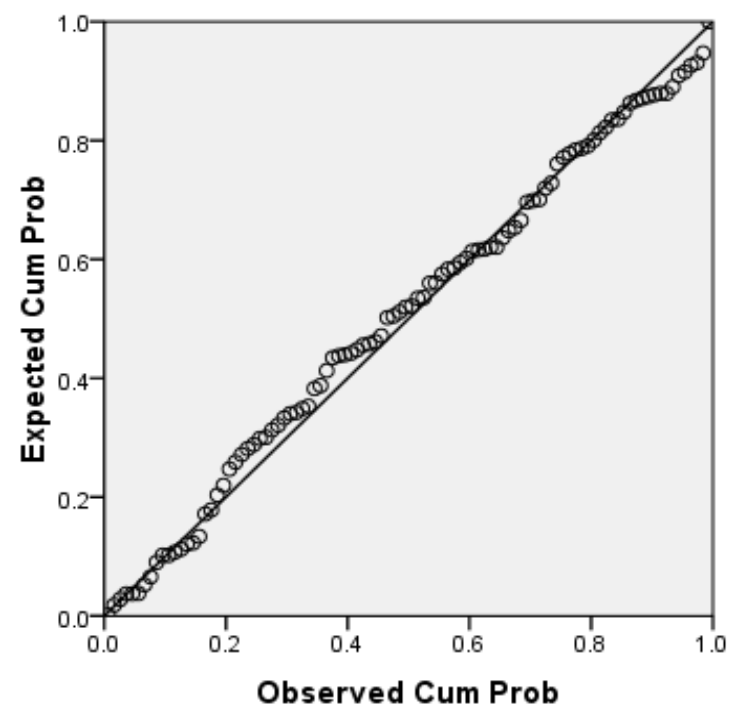

Sumber : Data Primer yang diolah, 2017 
Dari Grafik Normal P-P Plot diatas terlihat titik-titik menyebar disekitar garis diagonal dan mengikuti arah garis diagonal. Dengan demikian data tersebut dapat dikatakan berdistribusi normal.

Uji Heteroskedastisitas

Gambar 3. Grafik Scatterplot

\section{Scatterplot}

Dependent Variable: Loyalitas

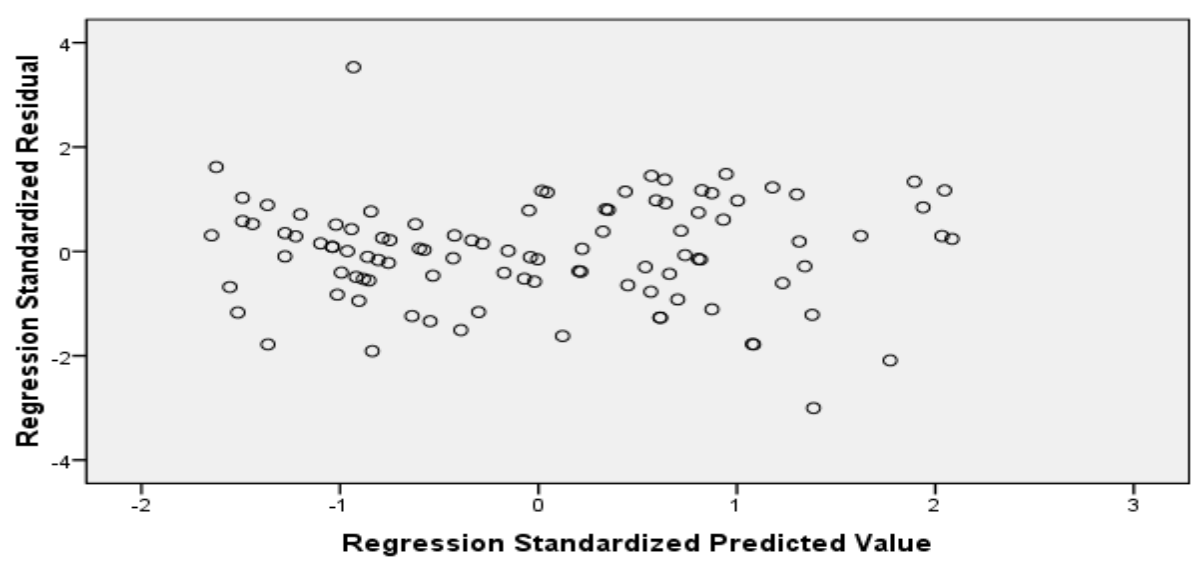

Sumber : Data Primer yang diolah, 2017

Dari grafik scatterplot diatas dapat dilihat bahwa titik-titik menyebar secara acak dan tidak berkumpul pada satu tempat. Hal ini membuktikan bahwa dalam data tidak terjadi problem heterokdasitas.

\section{Koefisien Determinasi}

Koefisien determinasi memiliki fungsi untuk menjelaskan sejauh mana kemampuan variabel independenrelationship marketing, citra perusahaan dan kepuasan terhadap variabel dependen loyalitas nasabah dengan melihat $\mathrm{R}$ square. 
Hasil koefisien determinasi dapat dilihat pada tabel di bawah ini:

Tabel 3. Hasil Koefisien Determinasi

\begin{tabular}{llrrrrr}
\multicolumn{6}{c}{ Model Summary } \\
\hline Model & $\mathrm{R}$ & $\mathrm{R}$ Square & \multicolumn{2}{c}{$\begin{array}{c}\text { Adjusted R } \\
\text { Square }\end{array}$} & $\begin{array}{c}\text { Std. Error of the } \\
\text { Estimate }\end{array}$ & Durbin-Watson \\
\hline 1 & $.742^{\mathrm{a}}$ & .551 & & .537 & 2.24775 & 1.824 \\
\hline
\end{tabular}

a. Predictors: (Constant), Kepuasan, Relationship, Citra

b. Dependent Variable: Loyalitas

Sumber : Data Primer yang diolah, 2017

Hasil analisis data pada variabel loyalitas nasabah terlihat bahwa $\mathrm{R}$ square sebesar 0.551 atau 55,1\%. Hal ini menunjukkan bahwa variabel independen yaitu relationship marketing, citra perusahaan dan kepuasan hanya mampu menjelaskan variabel dependen sebesar 55,1\%, sisanya 44,9\% dijelaskan oleh variabel lain yang tidak ada atau tidak diperhitungkan dalam analisis penelitian.

\section{Uji Parsial ( $\mathrm{t}$ test)}

Uji parsial ini memiliki tujuan untuk menguji atau mengkonfirmasi hipotesis secara individual antara variabel independen relationship marketing, citra perusahaan dan kepuasan secara parsial mempunyai pengaruh yang signifikan terhadap variabel dependen loyalitas nasabah. Hasil $t$ test ini dijelaskan pada tabel berikut ini:

Tabel 4

Hasil Uji Parsial (t test)

\begin{tabular}{|c|c|c|c|c|c|c|c|c|}
\hline \multicolumn{9}{|c|}{ Coefficients $^{a}$} \\
\hline & \multirow[t]{2}{*}{ Model } & \multicolumn{2}{|c|}{$\begin{array}{l}\text { Unstandardized } \\
\text { Coefficients }\end{array}$} & \multirow{2}{*}{$\begin{array}{c}\text { Standardized } \\
\text { Coefficients } \\
\text { Beta }\end{array}$} & \multirow[t]{2}{*}{$\mathrm{t}$} & \multirow[t]{2}{*}{ Sig. } & \multicolumn{2}{|c|}{ Collinearity Statistics } \\
\hline & & B & Std. Error & & & & Tolerance & $\mathrm{VIF}$ \\
\hline \multirow{4}{*}{1} & (Constant) & -.343 & 1.204 & & -.285 & .776 & & \\
\hline & Relationship & .382 & .083 & .409 & 4.625 & .000 & .598 & 1.673 \\
\hline & Citra & .200 & .086 & .213 & 2.315 & .023 & .550 & 1.817 \\
\hline & Kepuasan & .257 & .097 & .245 & 2.661 & .009 & .551 & 1.816 \\
\hline
\end{tabular}

a. Dependent Variable: Loyalitas

Sumber : Data Primer yang diolah, 2017 
Dari tabel 2 di atas, variabel relationship marketing menunjukkan nilai t hitung sebesar 4.625 dan $p$ value (sig) sebesar 0,000 yang di bawah alpha 0,05. Artinya bahwa variabelrelationship marketing berpengaruh terhadap loyalitas nasabah . Variabel citra perusahaan menunjukkan nilai t hitung sebesar 2.315 dan $p$ value (sig) sebesar 0,023 yang di bawah alpha 0,05. Artinya bahwa citra perusahaan berpengaruh terhadap loyalitas nasabah. Begitu juga dengan variable Kepuasan menunjukkan nilai t hitung sebesar 2.661 dan $p$ value (sig) sebesar 0,009 yang di bawah alpha 0,05. Artinya bahwa kepuasan juga berpengaruh terhadap loyalitas nasabah.

Adapun persamaan regresi yang diperoleh dari koefisien regresi variabel relationship marketing (X1), citra perusahaan (X2) dan kepuasan (X3) terhadap loyalitas nasabah (Y) adalah sebagai berikut:

$\mathrm{Y}=-0,343+0,382 \mathrm{X} 1+0,200 \mathrm{X} 2+0,257 \mathrm{X} 3+\mathrm{e}$

Pengaruh Relationship Marketing Terhadap Loyalitas Nasabah

Variabel relationship marketing (X1) memiliki pengaruh positif dan signifikan terhadap loyalitas nasabah. Relationship marketing berupaya menjalin hubungan jangka panjang dengan para pelanggan, dimana terdapat hubungan yang kokoh dan saling menguntungkan antara penyedia jasa dan pelanggan yang dapat membangun transaksi ulangan dan menciptakan loyalitas pelanggan (Murry, 2010:72). Dengan membangun hubungan yang baik dengan pelanggan maka keinginan pelanggan untuk melanjutkan hingga menuju kepada kesetiaan jangka panjang tidak diragukan lagi. Hasil penelitian ini mendukung penelitian sebelumnya yang dilakukan oleh Nita, 2016 yang menemukan bahwa citra perusahan yang baik terhadap nasabah akan meningkatkan loyalitas nasabah.

Pengaruh Citra Perusahaan Terhadap Loyalitas Nasabah

Variabel citra perusahaan (X2) memiliki pengaruh positif dan signifikan terhadap loyalitas nasabah. Citra adalah apa yang dipikirkan konsumen tentang suatu produk. Termasuk didalamnya adalah persepsi dan sikap yang didasarkan pada reaksi dan 
rangsangan yang berkaitan dengan perusahaan yang diterima melalui kelima indera (Peter dan Olson, 2000:248-24). Kotler (1997:57). Perusahaan selalu meningkatkan citra agar konsumen setia pada produk atau jasa yang dijualnya, karena dengan semakin banyaknya konsumen yang setia maka penjualan akan semakin meningkat, biaya pemasaran dapat berkurang dan timbulnya kemungkinan untuk menarik konsumen baru. Setia tidaknya konsumen pada suatu produk/jasa dapat dilihat dari sikapnya. Seberapa kuat citra perusahaan tertanam dalam benak atau ingatan konsumen berpengaruh terhadap perilaku atau sikap pelanggan selanjutnya, jika citra dari sebuah perusahaan baik maka pelanggan akan memiliki rasa kebanggan menjadi pengguna dari produk atau jasa tersebut. Hasil penelitian ini mendukung penelitian sebelumnya yang dilakukan oleh Arina, 2016 yang menemukan bahwa citra perusahan yang baik terhadap nasabah akan meningkatkan loyalitas nasabah.

Pengaruh Kepuasan Terhadap Loyalitas Nasabah

Variabel kepuasan (X3) memiliki pengaruh positif dan signifikan terhadap loyalitas nasabah.Menurut Zeithaml dan Bitner (2000) kepuasan adalah respon atau tanggapan konsumen mengenai pemenuhan kebutuhan. Kepuasan merupakan penilaian mengenai ciri atau keistimewaan produk atau jasa, atau produk itu sendiri, yang menyediakan tingkat kesenangan konsumen berkaitan dengan pemenuhan kebutuhan konsumsi konsumen. Kepuasan pelanggan adalah perasaan senang atau kecewa seseorang yang berasal dari perbandingan antara kesannya terhadap kinerja atau hasil suatu produk dan harapan-harapan (Kotler, et al., 2002). Konsumen yang merasa puas akan cenderung melakukan pembelian ulang terhadap suatu produk, dalam hal perbankan berarti adalah melakukan transaksi di tempat yang sama dan menceritakan pengalamannya terhadap orang lain. Maka dari itu nasabah yang puas akan cenderung loyal, sehingga untuk dapat membangun loyalitas nasabah, salah satu caranya adalah dengan memberikan kepuasan. Hasil penelitian ini mendukung penelitian sebelumnya yang dilakukan oleh Nita, 2016 yang menemukan bahwa kepuasan yang tinggi akan meningkatkan loyalitas nasabah. 


\section{Kesimpulan}

Dengan melihat hasil penelitian yang telah dibahas, maka dapat kita tarikkesimpulan bahwa variabel relationship marketing (X1) memiliki pengaruh signifikan terhadap loyalitas nasabah, hal ini ditunjukkan pvalue ( $\mathrm{sig}$ ) sebesar 0,000 di bawah 0,05.Variabel citra perusahaan (X2) memiliki pengaruh signifikan terhadap loyalitas nasabah, hal ini ditunjukkan pvalue (sig) sebesar 0,023 di bawah 0,05.Begitu juga dengan variabel kepuasan (X3) memiliki pengaruh signifikan terhadap loyalitas nasabah, hal ini ditunjukkan dengan pvalue (sig) sebesar 0,009 di bawah 0,05.

\section{Daftar Pustaka}

Abdullah, Ma’ruf, Wirausaha Berbasis Syariah, Banjarmasin, Antasari Press, 2011

Abdullah, Thamrin Dan Francis Tantri. 2013. Manajemen Pemasaran. Jakarta. PT Raja Grafindo Persada.

Aryani, D dan Rosinta, F. 2010. Pengaruh kualitas Layanan Terhadap Kepuasan Pelanggan dalam Membentuk Loyalitas Pelanggan. Jurnal Ilmu Administrasi dan Organisasi.Vol.17.No.2.

Assauri, Sofyan. 2011. Manajemen Pemasaran. Jakarta.PT Raja Grafindo Persada, 2011.

Hasan, Ali. 2010. Marketing Bank Syariah. Bogor. Ghalia Indonesia.

Istijanto, M.M.,M.Com. (2005), Riset Sumber Daya Manusia, PT. Gramedia Pustaka Utama, Jakarta.

Jasfar, Farida Prof. Dr., M.E. (2005), Manajemen Jasa, Ghalia Indonesia, Bogor.

Kasmir. 2004. Pemasaran Bank. Prenada Media. Jakarta.

Kotler, Philip And Gary Amstrong. 1997. Marketing Management: Analysis, Planning, Implementation and Control. 8td ed. Englewood Cliffs. New Jersey: Prentice Hall International, Inc.

Kotler, Philip. 2006. Manajemen Pemasaran edisi 12. Indonesia. PT Macanan Jaya Cemerlang. 
Kotler, Philip. 2000. Marketing Management, The Millenium Edition, Internatioal Edition. New Jersey. Prentice Hall International Inc.

Kotler, P., and Keller, K.L. 2012. Marketing Management. 14th. Ed. New Jersey. Pearson Education. Inc.

Muhammad, Metode Penelitian Ekonomi Islam, Jakarta, PT Raja Grafindo Persada, 2008.

Nova, Firsan. 2011. Crisis Public Relatons Bagaimana PR Menangani Krisis Perusahaan. Jakarta: Raja Grafindo Persada.

Nurudin. 2017. Pengaruh Sharia Marketing terhadap Loyalitas Anggota KSPPS BMT Walisongo Semarang. ", IAIN Salatiga.muqtasid.iainsalatiga.ac.id/index.php/ muqtasid/article/view/1076/730

Paul, J. Peter dan Jerry C. Olson. 2000. Consumer Behavior: Perilaku Konsumen dan Strategi Pemasaran. Terjemahan. Jakarta: Erlangga

Santoso, Singgih, Fandy, Tjiptono, Riset Pemasaran konsep dan Aplikasi dengan SPSS, Jakarta, PT Elex Media Komputindo, 2001.

Saputra, Murry Harmawan. 2010. Pengaruh Relationship Marketing Terhadap Loyalitas Mahasiswa Program Magister Sains Fakultas Ekonomika dan Bisnis Universitas Gajah Mada Yogyakarta. Universitas Muhammadiyah Purworejo.

Shanka, Mesay Sata. 2012. Bank Service Quality, Customer Satisfaction and Loyalty in Ethiopian Banking Sector. Journal of Business Administration and Management Sciences Research. December 2012. Vol. 1

Sugiyono. 2004. Metode Penelitian Bisnis: Penerbit CV. Alfabeta: Bandung

Tjiptono, Fandy, Pemasaran Strategi, Andi Yogyakarta, edisi dua, 2012.

Woran Nita, Altje Tumbel, Paulina Van Rate. 2016. Pengaruh Costumer Relationship Marketing, Nilai, Keunggulan Produk Dan Kepuasan Terhadap Loyalitas Nasabah (Studi Pada Bank Mega Jl. Piere Tendean Mega Mall Manado).

Zeithaml, Valarie A. Mry Jo Bitner. (2000). Services Marketing: Integrating Customer Focus Across The Firm, Second Edition Hill. . New York: McGraw

Zuriah, Nurul. 2006. Metode Penelitian Sosial dan Pendidikan. Jakarta: Bumi Aksara 